\title{
Experimental Measurements and Numerical Analysis of Al Deoxidation Equilibrium of Molten Fe-Cr-Ni Alloy
}

\author{
Hiroshi FUKAYA, ${ }^{1) *}$ Seika NAKAJIMA, ${ }^{2)}$ Jonah GAMUTAN, ${ }^{3)}$ Shigeru SUZUKI, ${ }^{1)}$ Koji KAJIKAWA, ${ }^{1)}$ Ken SAITO ${ }^{4)}$ \\ and Takahiro $\mathrm{MIKI}^{3)}$ \\ 1) Japan Steel Works M\&E, Inc. Muroran Research Laboratory, 4, Chatsumachi, Muroran, 051-8505 Japan. \\ 2) Graduate Student, Department of Metallurgy, Graduate School of Engineering, Tohoku University, Aoba-yama 6-6-02, \\ Sendai, 980-8579 Japan. \\ 3) Department of Metallurgy, Graduate School of Engineering, Tohoku University, Aoba-yama 6-6-02, Sendai, 980-8579 Japan. \\ 4) JSW Joint Research Division, Graduate School of Engineering, Tohoku University, Aoba-yama 6-6-02, Sendai, 980-8579 \\ Japan.
}

(Received on November 26, 2020; accepted on March 12, 2021)

\begin{abstract}
The aluminum deoxidation equilibrium in molten Fe-10 to 40 mass $\% \mathrm{Cr}-8 \mathrm{mass} \% \mathrm{Ni}$ and $\mathrm{Fe}-18 \mathrm{mass} \% \mathrm{Cr}-8$ to 30 mass $\% \mathrm{Ni}$ alloys was experimentally determined at $1873 \mathrm{~K}$ and $1773 \mathrm{~K}$ to obtain the thermodynamic parameters at both temperatures, corresponding to the refining and casting processes, respectively. Thermodynamic analysis on Al deoxidation was carried out based on the sub-regular solution model using a Redlich-Kister type polynomial. Fe-Al, $\mathrm{Ni}-\mathrm{Al}, \mathrm{Cr}-\mathrm{Al}$ and $\mathrm{Fe}-\mathrm{Cr}-\mathrm{Ni}$ interaction parameters were obtained from experimental results and a thermodynamic assessment. Using these parameters, the Al deoxidation equilibrium over the complete composition range of the Fe-Ni alloy and in more than 50mass\% Fe of the $\mathrm{Fe}-\mathrm{Cr}$ and $\mathrm{Fe}-\mathrm{Cr}-\mathrm{Ni}$ alloys can be calculated for the temperature ranges of both of the refining and casting processes.
\end{abstract}

KEY WORDS: quadratic formalism; thermodynamics; activity; excess free Gibbs energy; Redlich-Kister polynomial; aluminum deoxidation equilibrium; $\mathrm{Fe}-\mathrm{Cr}-\mathrm{Ni}$ alloy; sub-regular solution model: inclusion.

\section{Introduction}

Steels alloyed with chromium and nickel are some of the most popular alloy steels in the industry. Due to their excellent properties, $\mathrm{Fe}-\mathrm{Cr}-\mathrm{Ni}$ alloys are used in many applications as stainless steel, low-temperature steel, tool steel, heat-resistant steel, and so on.

To produce high quality steel, controlling the oxygen content in steel by deoxidation is important. Due to its strong affinity with oxygen and its availability, aluminum is commonly used as a deoxidizing agent during the steelmaking process. Therefore, several studies on the Al deoxidation equilibrium in the molten $\mathrm{Fe}-\mathrm{Ni}$ and $\mathrm{Fe}-\mathrm{Cr}$ binary alloys have been conducted.

So far, the $\mathrm{Al}$ deoxidation equilibrium in the $\mathrm{Fe}-\mathrm{Cr}$ alloy system have been investigated by the following: Kishi et al. ${ }^{1)}$ in $\mathrm{Fe}-20 \mathrm{mass} \% \mathrm{Cr}$ at $1873 \mathrm{~K}$, Ohta \& Suito $^{2}$ in $\mathrm{Fe}-8,20$, $40 \mathrm{mass} \% \mathrm{Cr}$ at $1873 \mathrm{~K}$, and Lee et al. ${ }^{3)}$ in $\mathrm{Fe}-16 \mathrm{mass} \% \mathrm{Ni}$ at $1923 \mathrm{~K}$ by using levitation furnace. Ogasawara et al. ${ }^{4)}$ also investigated $\mathrm{Al}$ deoxidation equilibrium in $\mathrm{Fe}-10,20$, $30,40 \mathrm{mass} \% \mathrm{Cr}$ with $\mathrm{Al}_{2} \mathrm{O}_{3}$ crucible at 1873,1823 and

\footnotetext{
* Corresponding author: E-mail: hiroshi_fukaya@jsw.co.jp
}

$1973 \mathrm{~K}$.

In addition, the $\mathrm{Al}$ deoxidation equilibrium in the $\mathrm{Fe}-\mathrm{Ni}$ alloy system have been studied by the following: Katsuki \& Yamauchi $^{5)}$ in $\mathrm{Fe}-36 \% \mathrm{Ni}$ at $1873 \mathrm{~K}$, Cho \& Suito ${ }^{6)}$ in $\mathrm{Fe}-30,50,70 \mathrm{mass} \% \mathrm{Ni}$ at $1873 \mathrm{~K}$, Li et al. ${ }^{7)}$ in $\mathrm{Fe}-36 \% \mathrm{Ni}$ with a mullite crucible at $1873 \mathrm{~K}$, Ishii et al ${ }^{8)}$ in $\mathrm{Fe}-50,60$, $70,80,90 \% \mathrm{Ni}$ at $1873,1923,1973 \mathrm{~K}$ and $\mathrm{Ni}$ at 1823 to $1973 \mathrm{~K}$, Fujiwara et al. ${ }^{9)}$ in $\mathrm{Fe}-36 \mathrm{mass} \% \mathrm{Ni}$ at $1973 \mathrm{~K}$, Lee et al. ${ }^{10)}$ in $\mathrm{Fe}-36 \mathrm{mass} \% \mathrm{Ni}$ alloy at $1773 \mathrm{~K}$ by using levitation furnace, Ohta \& Suito ${ }^{2)}$ in Fe-10, 20, 40, 60mass\%Ni at $1873 \mathrm{~K}$, Hayashi et al. ${ }^{11)}$ in Fe-20, 40mass\% $\% \mathrm{Ni}$ at 1873,1923 and $1973 \mathrm{~K}$, and Fukaya et al. ${ }^{12)}$ in Fe-36, $46 \mathrm{mass} \% \mathrm{Ni}$ at 1773 and $1873 \mathrm{~K}$.

However, despite the importance of $\mathrm{Fe}-\mathrm{Cr}-\mathrm{Ni}$ alloy in the industry, the $\mathrm{Al}$ deoxidation equilibrium in $\mathrm{Fe}-\mathrm{Cr}-\mathrm{Ni}$ alloy has only been reported by Ohta \& Suito. ${ }^{2)}$ They investigated the $\mathrm{Al}$ deoxidation equilibrium in $\mathrm{Fe}-18 \mathrm{mass} \% \mathrm{Cr}$ 8 mass $\% \mathrm{Ni}$ alloy at $1873 \mathrm{~K}$ equilibrated with $\mathrm{CaO}-\mathrm{Al}_{2} \mathrm{O}_{3}$ slag. Although $\mathrm{Fe}-18$ mass $\% \mathrm{Cr}-8$ mass $\% \mathrm{Ni}$ is the most common $\mathrm{Fe}-\mathrm{Cr}-\mathrm{Ni}$ alloy, it is not enough to obtain the thermodynamic parameters to calculate the $\mathrm{Al}$ deoxidation equilibrium in $\mathrm{Fe}-\mathrm{Cr}-\mathrm{Ni}$ alloys due to the wide composition range of practical $\mathrm{Fe}-\mathrm{Cr}-\mathrm{Ni}$ alloys. Furthermore, most 
of these studies were carried out at temperature of $1873 \mathrm{~K}$ or higher, because these studies were intended to describe and/or predict the reactions during the steel-refining process. However, to control the secondary inclusions that form due to cooling and solidification during the casting process, thermodynamic information around the liquidus temperature is also required. This issue has become much more important due to the increasing demand for ultra-high clean steels such as bearing steels, functional thin steel foils, and so on.

In this study, $\mathrm{Al}$ deoxidation equilibrium in molten $\mathrm{Fe}-10$ to 40 mass $\% \mathrm{Cr}-8 \mathrm{mass} \% \mathrm{Ni}$ and $\mathrm{Fe}-18 \mathrm{mass} \% \mathrm{Cr}-8$ to $30 \mathrm{mass} \% \mathrm{Ni}$ alloys was experimentally measured at $1873 \mathrm{~K}$ and $1773 \mathrm{~K}$ to describe the $\mathrm{Al}$ deoxidation equilibrium in $\mathrm{Fe}-\mathrm{Cr}-\mathrm{Ni}$ alloys. This is necessary to predict and/or control the $\mathrm{Al}$ deoxidation reaction at the refining and casting temperatures. Further, a thermodynamic assessment was carried out to obtain the interaction parameters based on the experimental results and reported studies. Using the parameters in this study, the $\mathrm{Al}$ deoxidation equilibrium over the complete composition range of $\mathrm{Fe}-\mathrm{Ni}$ alloys and in the composition range of more than 50 mass $\% \mathrm{Fe}$ in $\mathrm{Fe}-\mathrm{Cr}$ and $\mathrm{Fe}-\mathrm{Cr}-\mathrm{Ni}$ alloys can be calculated at the temperature ranges of both the refining and casting processes.

\section{Experiment}

In this study, the $\mathrm{Al}$ deoxidation experiments were carried out in $\mathrm{Fe}-10,18,30,40 \mathrm{mass} \% \mathrm{Cr}-8$ mass $\% \mathrm{Ni}$ and $\mathrm{Fe}-$ $18 \mathrm{mass} \% \mathrm{Cr}-8,20,30 \mathrm{mass} \% \mathrm{Ni}$ alloys using an induction furnace at $1773 \mathrm{~K}$ and $1873 \mathrm{~K}$. The experimental procedure is as follows. Reagent-grade electrolytic Fe (99.9\% purity), Ni (99.9\% purity) and Cr (99\% purity) were used to prepare about 25 grams of alloy samples. High-purity $\mathrm{Al}$ (99.99\% purity) or prepared $\mathrm{Ni}-5$ mass $\% \mathrm{Al}$ alloy was used as the deoxidizer.

For enhanced reliability of the experimental results, equilibrated samples were obtained by melting twice in an $\mathrm{Al}_{2} \mathrm{O}_{3}$ crucible using a high-frequency induction furnace. Since the starting materials contain hundreds mass ppm of oxygen higher than the $\mathrm{Al}$ deoxidation equilibrium, $\mathrm{Al}_{2} \mathrm{O}_{3}-\mathrm{Cr}_{2} \mathrm{O}_{3}$ solid solution easily formed in the interface of $\mathrm{Al}_{2} \mathrm{O}_{3}$ crucible before deoxidation by $\mathrm{Al}$ or $\mathrm{Ni}-\mathrm{Al}$ alloy. Once an $\mathrm{Al}_{2} \mathrm{O}_{3}-\mathrm{Cr}_{2} \mathrm{O}_{3}$ solid solution is formed, the complete reduction of $\mathrm{Cr}_{2} \mathrm{O}_{3}$ from the solid solution will be difficult. Therefore, in this study, the raw materials were first melted as a preliminary deoxidation step. After polishing the surface and cutting off the top part of the sample to remove the deoxidation products, the sample was melted again to obtain the equilibrated sample.

The melting procedure in the first and second melts were the same. Samples were placed in an $\mathrm{Al}_{2} \mathrm{O}_{3}$ crucible (OD: $21 \mathrm{~mm}$, ID: $17 \mathrm{~mm}$ and Height: $100 \mathrm{~mm}$ ) and heated in an Ar atmosphere $(1.0 \mathrm{~L} / \mathrm{min})$ using a high-frequency induction heating furnace (MU-1700D, Sekisui Chemical Co., Ltd.) as shown in Fig. 1. Sample temperature was measured using a radiation thermometer (FTK-9, Japan Sensor Co., Ltd.). The emissivity of the radiation thermometer was calibrated by comparing the liquidus temperature of the $\mathrm{Fe}-\mathrm{Ni}-\mathrm{Cr}$ alloy. After the sample was completely melted at $1873 \mathrm{~K}$, $\mathrm{Al}$ or $\mathrm{Ni}-\mathrm{Al}$ alloy was added to the molten sample through the injection pipe, and the sample was held at $1873 \mathrm{~K}$ or

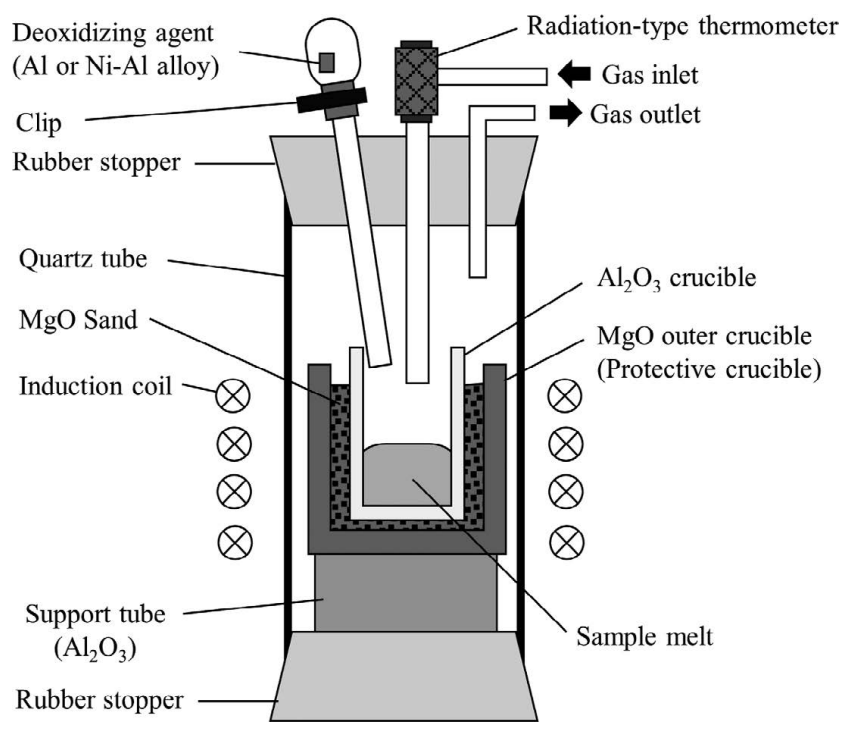

Fig. 1. Schematic diagram of the experimental setup.

$1773 \mathrm{~K}$ for another 20 minutes which was confirmed to be enough to reach equilibrium from the preliminary experiments. The sample melt was then quenched by cutting off the furnace power.

The chemical composition of the equilibrium samples was analyzed using the following techniques. After removing the shrinkage cavities from the equilibrium sample, the oxygen content was determined by an inert gas fusion technique (LECO-ONH836 Element Analyzer) using from about 0.3 to $1.0 \mathrm{~g}$ of samples. Due to the removal of the preliminary deoxidation products by double melting and the pinch effect of the induction furnace, the analyzed oxygen content is assumed to be the dissolved oxygen in the metal phase. Meanwhile, the $\mathrm{Cr} \mathrm{Ni}$ and $\mathrm{Al}$ contents in the equilibrium samples were determined using an inductively coupled plasma emission spectrometer (ICPS-8100, Shimadzu Corp.). Approximately 0.3 to $1.0 \mathrm{~g}$ of the sample were dissolved in an aqua regia solution prepared by mixing 3-parts $\mathrm{HCl}$ to 1-part $\mathrm{HNO}_{3}$. The Fe content of the samples was obtained as the remainder of the $\mathrm{Cr}, \mathrm{Ni}, \mathrm{Al}$ and $\mathrm{O}$.

\section{Experimental Results}

The chemical compositions of the metal phase of the $\mathrm{Fe}-$ $\mathrm{Cr}-\mathrm{Ni}$ alloys at $1873 \mathrm{~K}$ and $1773 \mathrm{~K}$ are shown in Tables $\mathbf{1}$ and 2, respectively. As mentioned before, in this study, the measured oxygen content was assumed to be the dissolved oxygen in the metal phase. The oxide composition at metal-crucible interface have been analyzed by SEMEDS and it is confirmed to be $\mathrm{Al}_{2} \mathrm{O}_{3}$ (>98 mass\%) in each experiments. So the activity of $\mathrm{Al}_{2} \mathrm{O}_{3}$ have been considered as unity in this paper. The $\mathrm{Al}-\mathrm{O}$ equilibrium relationship in $\mathrm{Fe}-10$ to 40 mass $\% \mathrm{Cr}-8$ mass $\% \mathrm{Ni}$ alloy and Fe- 18 mass $\% \mathrm{Cr}-8$ to $30 \mathrm{mass} \% \mathrm{Ni}$ at $1773 \mathrm{~K}$ and $1873 \mathrm{~K}$ are shown in Figs. 2 and 3, respectively, along with the values previously reported by Ohta \& Suito $^{2)}(\mathrm{Fe}-18 \mathrm{mass} \% \mathrm{Cr}-8 \mathrm{mass} \% \mathrm{Ni}$ at $1873 \mathrm{~K})$. Here, since Ohta \& Suito measured the Al deoxidation by equilibrating with $\mathrm{CaO}-\mathrm{Al}_{2} \mathrm{O}_{3} \operatorname{slag}\left(a_{\mathrm{Al}_{2} \mathrm{O}_{3}}=0.33\right)$, the oxygen content was converted into the value of $\mathrm{Al}_{2} \mathrm{O}_{3}$ activity equal to unity. The solid and dashed lines shows the calculated equilibrium at $1873 \mathrm{~K}$ and $1773 \mathrm{~K}$, respectively, 
Table 1. Composition of $\mathrm{Fe}-\mathrm{Cr}-\mathrm{Ni}$ alloys at $1873 \mathrm{~K}$.

\begin{tabular}{|c|c|c|c|}
\hline $\operatorname{mass} \% \mathrm{Cr}$ & mass $\% \mathrm{Ni}$ & mass $\% \mathrm{Al}$ & $\operatorname{mass} \% \mathrm{O}$ \\
\hline 9.67 & 7.76 & 0.00044 & 0.0239 \\
\hline 9.55 & 8.04 & 0.0015 & 0.0324 \\
\hline 9.72 & 7.87 & 0.0045 & 0.0058 \\
\hline 9.63 & 7.94 & 0.0340 & 0.0020 \\
\hline 9.58 & 8.23 & 0.129 & 0.0012 \\
\hline 17.64 & 7.98 & 0.0015 & 0.0184 \\
\hline 17.50 & 7.84 & 0.0021 & 0.0268 \\
\hline 17.53 & 7.93 & 0.0383 & 0.0023 \\
\hline 17.54 & 8.02 & 0.102 & 0.00087 \\
\hline 17.55 & 7.99 & 0.226 & 0.0010 \\
\hline 16.73 & 6.27 & 0.279 & 0.0014 \\
\hline 17.74 & 20.43 & 0.0013 & 0.0372 \\
\hline 17.84 & 20.45 & 0.0096 & 0.0084 \\
\hline 17.69 & 20.33 & 0.047 & 0.0045 \\
\hline 17.85 & 20.09 & 0.127 & 0.0037 \\
\hline 17.85 & 30.41 & 0.0285 & 0.0129 \\
\hline 17.62 & 29.99 & 0.0394 & 0.0070 \\
\hline 18.20 & 29.03 & 0.0441 & 0.0093 \\
\hline 18.02 & 30.35 & 0.0978 & 0.0033 \\
\hline 29.92 & 8.15 & 0.0032 & 0.0154 \\
\hline 29.65 & 7.93 & 0.0335 & 0.0103 \\
\hline 29.72 & 8.11 & 0.139 & 0.0054 \\
\hline 29.60 & 7.93 & 0.171 & 0.0044 \\
\hline 29.69 & 8.08 & 0.179 & 0.0025 \\
\hline 39.71 & 7.88 & 0.0023 & 0.0235 \\
\hline 40.26 & 6.82 & 0.0032 & 0.0208 \\
\hline 40.37 & 7.08 & 0.0048 & 0.0152 \\
\hline 40.28 & 6.59 & 0.169 & 0.0018 \\
\hline 39.88 & 6.56 & 0.249 & 0.0023 \\
\hline
\end{tabular}

as discussed in Section 4. The $\mathrm{Al}$ deoxidation equilibrium product, $\log K^{\prime}\left(=\log \left([\operatorname{mass} \% \mathrm{Al}]^{2}\left[\operatorname{mass}^{2} \%\right]^{3} / a_{\mathrm{Al}_{2} \mathrm{O}_{3}}\right)\right.$, in Fe$\mathrm{Cr}-8 \mathrm{mass} \% \mathrm{Ni}$ and $\mathrm{Fe}-18 \mathrm{mass} \% \mathrm{Cr}-\mathrm{Ni}$ alloys are shown in Figs. 4 and 5. Here, the reported values of Fe-10mass $\% \mathrm{Ni}$ $\left(\right.$ Ohta $\&$ Suito $^{2)}$ ) and Fe-20mass $\% \mathrm{Cr}\left(\right.$ Ohta \& Suito, ${ }^{2)} \mathrm{Kishi}^{1)}$ and Ogasawara ${ }^{4)}$ are also plotted. As shown in Fig. 4, the $\log K^{\prime}$ of $\mathrm{Fe}-\mathrm{Cr}-8$ mass $\% \mathrm{Ni}$ alloy increased with $\mathrm{Cr}$ content up to 30 mass $\%$, beyond which value it decrease with increasing $\mathrm{Cr}$ contents. A similar tendency is observed in Fig. 5. The $\log K^{\prime}$ of $\mathrm{Fe}-18$ mass $\% \mathrm{Cr}-\mathrm{Ni}$ alloy increased with $\mathrm{Ni}$ content up to $20 \mathrm{mass} \% \mathrm{Ni}$ and decreased with higher $\mathrm{Ni}$ content. These indicate that the $\mathrm{Al}$ deoxidation equilibrium in $\mathrm{Fe}-\mathrm{Cr}-\mathrm{Ni}$ alloy has a complex composition dependence which cannot be expressed in terms of a linear relationship.

\section{Analysis}

\subsection{Thermodynamic Model for the Al Deoxidation Equilibrium}

To describe the $\mathrm{Al}$ deoxidation equilibrium in $\mathrm{Fe}-\mathrm{Cr}-\mathrm{Ni}$
Table 2. Composition of $\mathrm{Fe}-\mathrm{Cr}-\mathrm{Ni}$ alloys at $1773 \mathrm{~K}$

\begin{tabular}{|c|c|c|c|}
\hline mass $\% \mathrm{Cr}$ & $\operatorname{mass} \% \mathrm{Ni}$ & mass $\% \mathrm{Al}$ & $\operatorname{mass} \% \mathrm{O}$ \\
\hline 9.72 & 7.83 & 0.0046 & 0.0032 \\
\hline 9.53 & 7.75 & 0.0140 & 0.0024 \\
\hline 9.67 & 7.83 & 0.0431 & 0.0010 \\
\hline 9.88 & 8.09 & 0.0468 & 0.0010 \\
\hline 9.54 & 7.76 & 0.0915 & 0.00084 \\
\hline 9.16 & 7.08 & 0.1232 & 0.0011 \\
\hline 17.55 & 7.10 & 0.00137 & 0.0122 \\
\hline 17.67 & 7.89 & 0.0426 & 0.00066 \\
\hline 17.48 & 8.20 & 0.0714 & 0.0011 \\
\hline 17.51 & 7.49 & 0.131 & 0.00053 \\
\hline 17.56 & 8.05 & 0.326 & 0.00061 \\
\hline 17.67 & 20.24 & 0.00078 & 0.0324 \\
\hline 17.94 & 20.21 & 0.0069 & 0.0030 \\
\hline 17.83 & 20.29 & 0.0089 & 0.0054 \\
\hline 17.86 & 20.26 & 0.0642 & 0.0021 \\
\hline 17.59 & 20.10 & 0.234 & 0.0020 \\
\hline 17.95 & 30.36 & 0.0102 & 0.0072 \\
\hline 18.11 & 30.34 & 0.0244 & 0.0046 \\
\hline 17.89 & 30.38 & 0.0291 & 0.0056 \\
\hline 17.93 & 30.17 & 0.0460 & 0.0046 \\
\hline 17.80 & 30.21 & 0.0567 & 0.0022 \\
\hline 29.69 & 7.82 & 0.00033 & 0.0233 \\
\hline 29.55 & 8.16 & 0.134 & 0.0020 \\
\hline 29.53 & 8.04 & 0.189 & 0.0016 \\
\hline 29.59 & 8.18 & 0.203 & 0.0014 \\
\hline 29.46 & 7.87 & 0.248 & 0.0016 \\
\hline 29.45 & 7.82 & 0.269 & 0.0025 \\
\hline 29.83 & 8.19 & 0.283 & 0.0022 \\
\hline 39.90 & 7.73 & 0.0017 & 0.0165 \\
\hline 39.49 & 7.42 & 0.0339 & 0.0023 \\
\hline 39.66 & 8.22 & 0.179 & 0.0018 \\
\hline 39.72 & 8.10 & 0.192 & 0.00073 \\
\hline 39.62 & 7.88 & 0.219 & 0.0013 \\
\hline 39.45 & 7.96 & 0.291 & 0.0011 \\
\hline
\end{tabular}

alloy, the sub-regular solution model with Redlich-Kister type polynomial ${ }^{13,14)}$ was used in this study, as was also applied to the $\mathrm{Si}$ deoxidation equilibrium by Miki \& Hino. ${ }^{15,16)}$

Wagner's type interaction parameter formalism (WIPF) ${ }^{17)}$ is the most popular method and commonly used in practical engineering. However, WIPF is, inherently, only available for dilute solutions. Although Kang et al. ${ }^{18)}$ described the $\mathrm{Al}$ deoxidation equilibrium of $\mathrm{Fe}$ with higher $\mathrm{Al}$ content by using secondary interaction parameters, there are many difficulties to applying WIPF to a wide composition range of high-alloy steels.

To describe the strong affinity between a deoxidizing element and oxygen, a modified quasi-chemical model (MQM) 


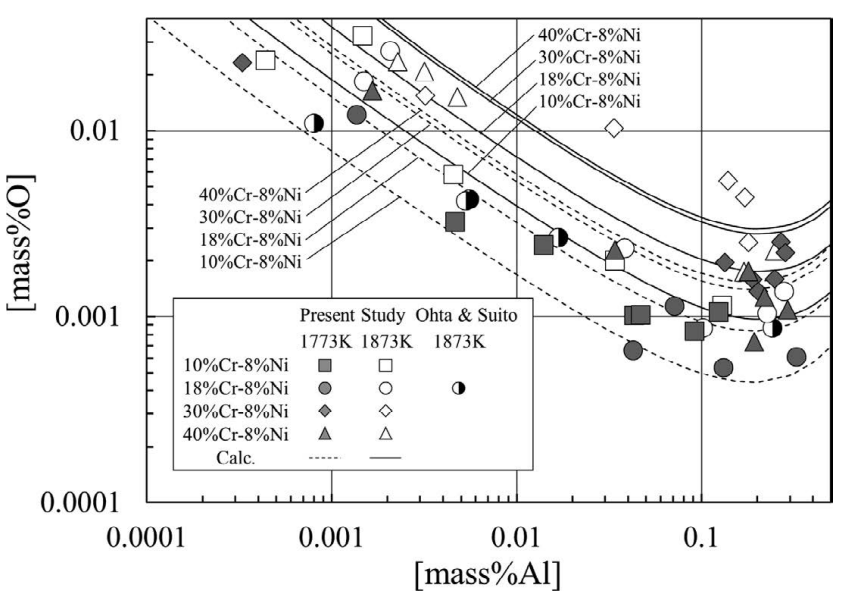

Fig. 2. Experimental results of $\mathrm{Fe}-10$ to $40 \mathrm{mass} \% \mathrm{Cr}-8 \mathrm{mass} \% \mathrm{Ni}$ alloys.

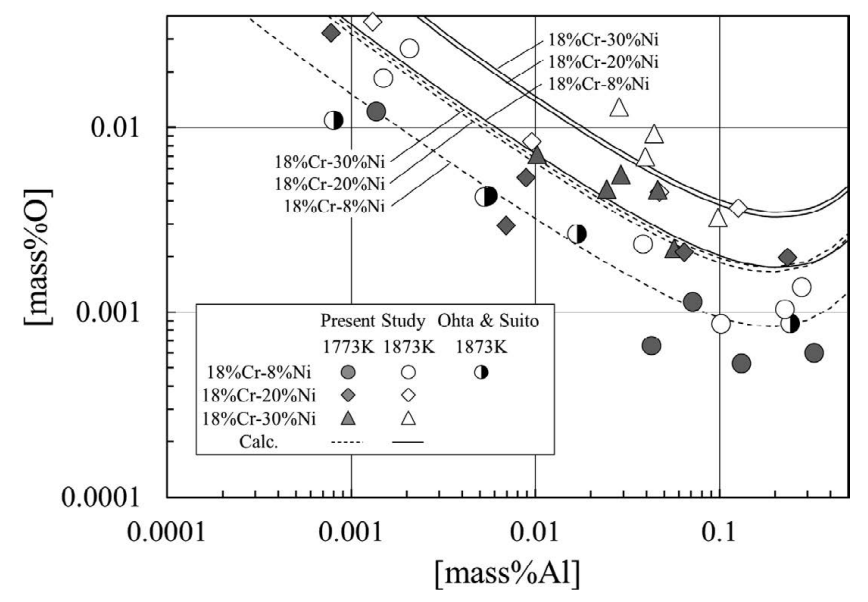

Fig. 3. Experimental results of $\mathrm{Fe}-18$ mass $\% \mathrm{Cr}-8$ to $30 \mathrm{mass} \% \mathrm{Ni}$ alloys.

has recently been developed. Paek et al. ${ }^{19,20)}$ have made it possible to describe the $\mathrm{Al}$ deoxidation equilibrium over the complete composition range of $\mathrm{Fe}-\mathrm{Al}$ alloys. However, evaluation in multiple high-alloy systems, such as ternary systems, was not enough.

On the other hand, the sub-regular solution model is widely used in phase diagram calculation. Our research group applied this model to the Ti deoxidation of $\mathrm{Fe},{ }^{21,22)}$ $\mathrm{Fe}-\mathrm{Ni}^{23)}$ and $\mathrm{Fe}-\mathrm{Cr}$ and $\mathrm{Fe}-\mathrm{Cr}-\mathrm{Ni}^{24}$ alloys, to the $\mathrm{Mg}$ deoxidation of $\mathrm{Fe}-\mathrm{Ni}^{25)}$ and $\mathrm{Fe}-\mathrm{Cr}-\mathrm{Ni}^{26)}$ alloys and to the $\mathrm{Al}$ deoxidation of $\mathrm{Fe}-\mathrm{Ni}$ alloy. ${ }^{11,12)}$ It was also confirmed that the sub-regular solution model is applicable to calculations of the deoxidation equilibriums of multiple high alloys.

The Al deoxidation equilibrium is described using the sub-regular solution model below. Using a Redlich-Kister type polynomial, the excess Gibbs free energy $\left(\Delta G^{e x}\right)$ is determined from Eq. (1).

$$
\begin{aligned}
\Delta G^{e x} & =\sum X_{i} X_{j}\left(X_{i}-X_{j}\right)^{n} \Omega_{i-j}^{n} \\
& +\sum X_{i} X_{j} X_{k}\left(Y_{i} \Omega_{i j k}^{i}+Y_{j} \Omega_{i j k}^{j}+Y_{k} \Omega_{i j k}^{k}\right)
\end{aligned}
$$

where $X_{i}$ is the molar fraction of element $i, \Omega_{i-j}^{n}$ denotes the $i-j$ binary interaction parameters, $\Omega_{i j k}^{i}$ denotes the $i-j-k$ ternary interaction parameters and $Y_{i}$ is the molar fraction of element $i$ standardized into the $i-j-k$ ternary system by Eqs. (2) to (4).

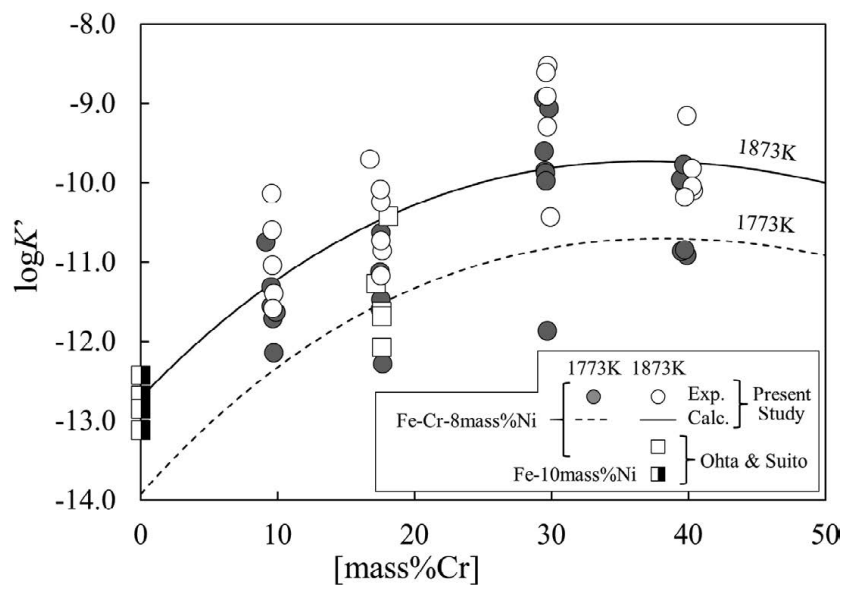

Fig. 4. $\log K^{\prime}$ of $\mathrm{Fe}-\mathrm{Cr}-8 \mathrm{mass} \% \mathrm{Ni}$ alloys at $1773 \mathrm{~K}$ and $1873 \mathrm{~K}$.

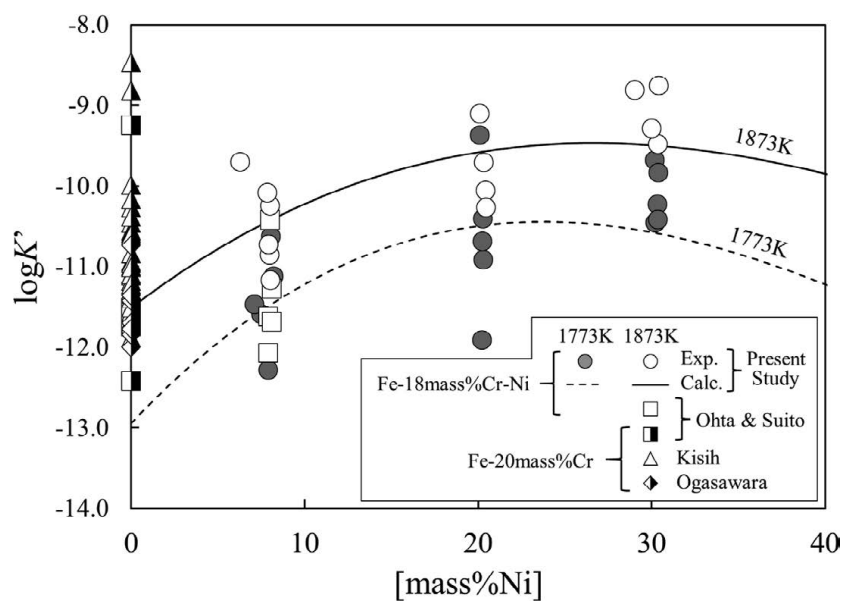

Fig. 5. $\log K^{\prime}$ of Fe-18mass\%Cr-Ni alloys at $1773 \mathrm{~K}$ and $1873 \mathrm{~K}$.

$$
\begin{gathered}
Y_{i}=X_{i} /\left(X_{i}+X_{j}+X_{k}\right) \\
Y_{j}=X_{j} /\left(X_{i}+X_{j}+X_{k}\right) \\
Y_{k}=X_{k} /\left(X_{i}+X_{j}+X_{k}\right)
\end{gathered}
$$

Using the excess Gibbs free energy change, the activity coefficients of $\mathrm{Al}$ and $\mathrm{O}$ are given by Eqs. (5) and (6), respectively.

$$
\begin{aligned}
R T \ln \gamma_{\mathrm{Al}} & =\Delta G^{e x}-X_{\mathrm{Cr}} \frac{\partial \Delta G^{e x}}{\partial X_{\mathrm{Cr}}}-X_{\mathrm{Ni}} \frac{\partial \Delta G^{e x}}{\partial X_{\mathrm{Ni}}}-X_{\mathrm{O}} \frac{\partial \Delta G^{e x}}{\partial X_{\mathrm{O}}} \\
& +\left(1-X_{\mathrm{Al}}\right) \frac{\partial \Delta G^{e x}}{\partial X_{\mathrm{Al}}} \\
R T \ln \gamma_{\mathrm{O}}= & \Delta G^{e x}-X_{\mathrm{Cr}} \frac{\partial \Delta G^{e x}}{\partial X_{\mathrm{Cr}}}-X_{\mathrm{Ni}} \frac{\partial \Delta G^{e x}}{\partial X_{\mathrm{Ni}}}-X_{\mathrm{Al}} \frac{\partial \Delta G^{e x}}{\partial X_{\mathrm{Al}}} \\
& +\left(1-X_{\mathrm{O}}\right) \frac{\partial \Delta G^{e x}}{\partial X_{\mathrm{Al}}}
\end{aligned}
$$

For example, $R T \ln \gamma_{\mathrm{Al}}$ of the $\mathrm{Fe}-\mathrm{Cr}-\mathrm{Ni}-\mathrm{Al}-\mathrm{O}$ system is described in Eq. (7). Here, ternary interaction terms except $\mathrm{Fe}-\mathrm{Cr}-\mathrm{Ni}$ and $\mathrm{Fe}-\mathrm{Ni}-\mathrm{Al}$ were omitted because there were 
many combinations. $R T \ln \gamma_{\mathrm{O}}$ is also obtained by exchanging $\mathrm{Al}$ for $\mathrm{O}$ in Eq. (7).

$$
\begin{aligned}
& R T \ln \gamma_{\mathrm{Al}}=-\sum(n+1) X_{\mathrm{Fe}} X_{\mathrm{Cr}}\left(X_{\mathrm{Fe}}-X_{\mathrm{Cr}}\right)^{n} \Omega_{\mathrm{Fe}-\mathrm{Cr}}^{n} \\
& -\sum(n+1) X_{\mathrm{Fe}} X_{\mathrm{Ni}}\left(X_{\mathrm{Fe}}-X_{\mathrm{Ni}}\right)^{n} \Omega_{\mathrm{Fe}-\mathrm{Ni}}^{n} \\
& -\sum(n+1) X_{\mathrm{Cr}} X_{\mathrm{Ni}}\left(X_{\mathrm{Cr}}-X_{\mathrm{Ni}}\right)^{n} \Omega_{\mathrm{Cr}-\mathrm{Ni}}^{n} \\
& +\sum X_{\mathrm{Fe}}\left(X_{\mathrm{Fe}}-X_{\mathrm{Al}}\right)^{n-1}\left\{X_{\mathrm{Fe}}-(n+1) X_{\mathrm{Al}}-(n+1) X_{\mathrm{Fe}} X_{\mathrm{Al}}+(n+1) X_{\mathrm{Al}}^{2}\right\} \Omega_{\mathrm{Fe}-\mathrm{Al}}^{n} \\
& +\sum X_{\mathrm{Cr}}\left(X_{\mathrm{Cr}}-X_{\mathrm{Al}}\right)^{n-1}\left\{X_{\mathrm{Cr}}-(n+1) X_{\mathrm{Al}}-(n+1) X_{\mathrm{Cr}} X_{\mathrm{Al}}+(n+1) X_{\mathrm{Al}}^{2}\right\} \Omega_{\mathrm{Cr}-\mathrm{Al}}^{n} \\
& +\sum X_{\mathrm{Ni}}\left(X_{\mathrm{Ni}}-X_{\mathrm{Al}}\right)^{n-1}\left\{X_{\mathrm{Ni}}-(n+1) X_{\mathrm{Al}}-(n+1) X_{\mathrm{Ni}} X_{\mathrm{Al}}+(n+1) X_{\mathrm{Al}}^{2}\right\} \Omega_{\mathrm{Ni}-\mathrm{Al}}^{n} \\
& -\sum(n+1) X_{\mathrm{Fe}} X_{\mathrm{O}}\left(X_{\mathrm{Fe}}-X_{\mathrm{O}}\right)^{n} \Omega_{\mathrm{Fe}-\mathrm{O}}^{n} \\
& -\sum(n+1) X_{\mathrm{Cr}} X_{\mathrm{O}}\left(X_{\mathrm{Cr}}-X_{\mathrm{O}}\right)^{n} \Omega_{\mathrm{Cr}-\mathrm{O}}^{n} \\
& -\sum(n+1) X_{\mathrm{Fe}} X_{\mathrm{O}}\left(X_{\mathrm{Fe}}-X_{\mathrm{O}}\right)^{n} \Omega_{\mathrm{Ni}-\mathrm{O}}^{n} \\
& -\sum X_{\mathrm{O}}\left(X_{\mathrm{Al}}-X_{\mathrm{O}}\right)^{n-1}\left\{X_{\mathrm{O}}-(n+1) X_{\mathrm{Al}}-(n+1) X_{\mathrm{Al}} X_{\mathrm{O}}+(n+1) X_{\mathrm{Al}}^{2}\right\} \Omega_{\mathrm{Al}-\mathrm{O}}^{n} \\
& -2 X_{\mathrm{Fe}} X_{\mathrm{Cr}} X_{\mathrm{Ni}}\left(Y_{\mathrm{Fe}} \Omega_{\mathrm{FeCrNi}}^{\mathrm{Fe}}+Y_{\mathrm{Cr}} \Omega_{\mathrm{FeCrNi}}^{\mathrm{Cr}}+Y_{\mathrm{Ni}} \Omega_{\mathrm{FeCrNi}}^{\mathrm{Ni}}\right) \\
& +X_{\mathrm{Fe}} X_{\mathrm{Ni}}\left(1-Y_{\mathrm{Al}}-2 X_{\mathrm{Al}}\right)\left(Y_{\mathrm{Fe}} \Omega_{\mathrm{FeNiAl}}^{\mathrm{Fe}}+Y_{\mathrm{Ni}} \Omega_{\mathrm{FeNiAl}}^{\mathrm{Ni}}+Y_{\mathrm{Al}} \Omega_{\mathrm{FeNiAl}}^{\mathrm{Al}}\right) \\
& +X_{\mathrm{Fe}} X_{\mathrm{Ni}} Y_{\mathrm{Al}} \Omega_{\mathrm{AlFeNi}}^{\mathrm{Al}}
\end{aligned}
$$

Miki \& Hino ${ }^{15,16)}$ applied this model to the calculation of the deoxidation equilibrium by taking the standard state of oxygen as the dissolved oxygen equilibrating with 1 atm of $\mathrm{O}_{2}$ gas. In this condition, the dissolution reaction of oxygen gas is expressed in Eq. (8) and its Gibbs free energy change is equal to zero (Eq. (9)).

$$
\begin{aligned}
& 2 \underline{\mathrm{O}}=\mathrm{O}_{2}(g) \\
& \Delta G^{\circ}=-R T \ln \frac{P_{\mathrm{O}_{2}}}{a_{\mathrm{O}}{ }^{2}}=0\left(\because P_{\mathrm{O}_{2}}=a_{\mathrm{O}}{ }^{2}\right)
\end{aligned}
$$

The $\mathrm{Al}$ deoxidation reaction and its Gibbs free energy change can be expressed as Eq. (10). Since Eq. (9) is equal to zero, Eq. (10) is equal to the Gibbs free energy of $\mathrm{Al}_{2} \mathrm{O}_{3}$ formation $\left(\Delta G_{f, \mathrm{Al}_{2} \mathrm{O}_{3}}^{\circ},{ }^{11)} \mathrm{Eq}\right.$. (11)) and Eq. (12) was obtained. By introducing the activity coefficient $\left(R T \ln \gamma_{\mathrm{Al}}, R T \ln \gamma_{\mathrm{O}}\right)$ described using the excess Gibbs free energy (Eqs. (5) and (6)) into Eq. (12), the Al deoxidation equilibrium is calculated using the molar fraction and interaction parameters. In this study, a thermodynamic assessment was carried out based on this equation.

$$
\begin{aligned}
& 2 \underline{\mathrm{Al}}+3 \underline{\mathrm{O}}=\mathrm{Al}_{2} \mathrm{O}_{3}: \Delta G^{\circ}=R T \ln \frac{a_{\mathrm{Al}}^{2} a_{\mathrm{O}}^{3}}{a_{\mathrm{Al}_{2} \mathrm{O}_{3}}} \\
& 2 \mathrm{Al}(l)+\frac{3}{2} \mathrm{O}_{2}(g)=\mathrm{Al}_{2} \mathrm{O}_{3}(s): \Delta G_{\mathrm{Al}_{2} \mathrm{O}_{3}}^{\circ} \\
& =-1682300+324.15 T^{27)} \\
& \Delta G_{\mathrm{Al}_{2} \mathrm{O}_{3}}^{\circ}=R T \ln \frac{a_{\mathrm{Al}}^{2} a_{\mathrm{O}}^{3}}{a_{\mathrm{Al}_{2} \mathrm{O}_{3}}} \\
& =R T \ln X_{\mathrm{Al}}^{2} X_{\mathrm{O}}^{3}+2 R T \ln \gamma_{\mathrm{Al}}+3 R T \ln \gamma_{\mathrm{O}}-R T \ln a_{\mathrm{Al}_{2} \mathrm{O}_{3}}
\end{aligned}
$$

\subsection{Re-assessment in the $\mathrm{Fe}-\mathrm{Ni}-\mathrm{Al}-\mathrm{O}$ System}

The interaction parameters for the $\mathrm{Fe}-\mathrm{Ni}-\mathrm{Al}-\mathrm{O}$ system were determined in a previous study. ${ }^{12)}$ Although the $\mathrm{Al}$ deoxidation equilibrium over the complete composition range of $\mathrm{Fe}-\mathrm{Ni}$ alloys was calculated using these parameters, the $\mathrm{Ni}-\mathrm{Al}$ interaction parameters are inconsistent in

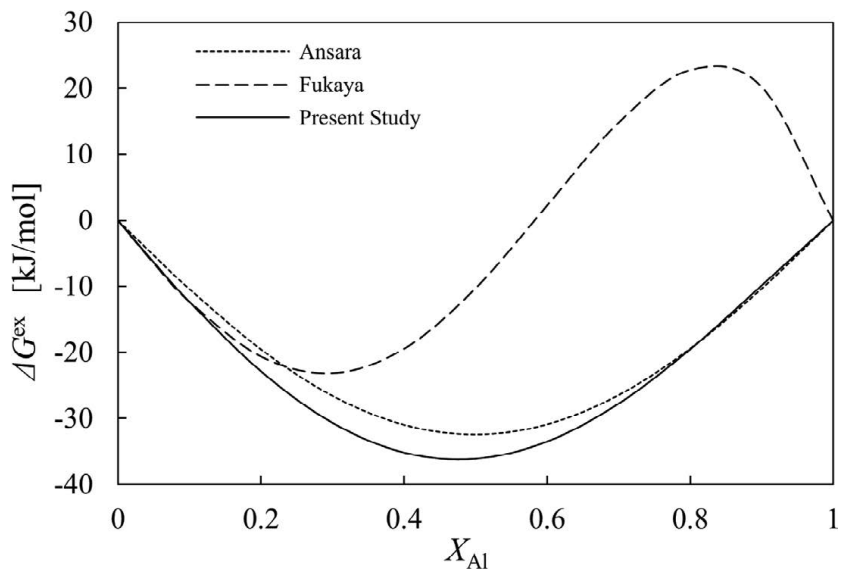

Fig. 6. Excess free energy of the $\mathrm{Ni}-\mathrm{Al}$ system at $1873 \mathrm{~K}$.

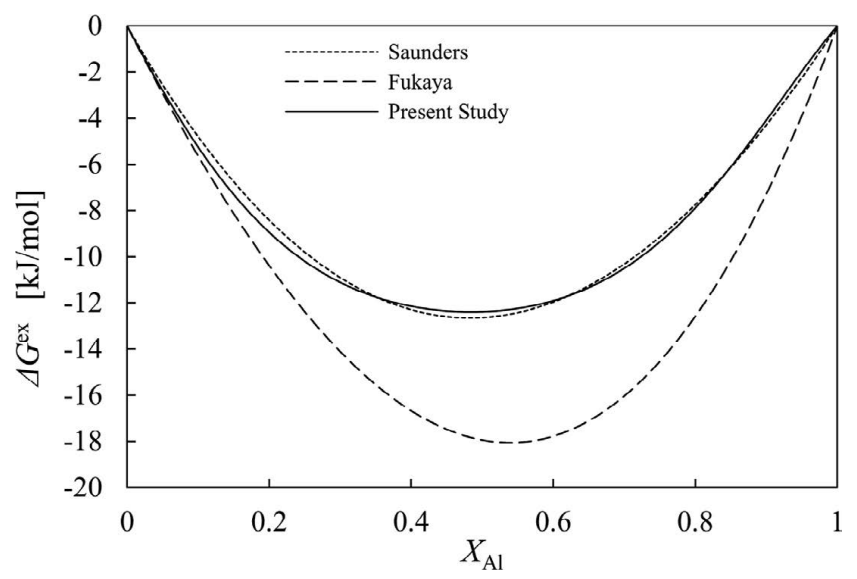

Fig. 7. Excess free energy of the $\mathrm{Fe}-\mathrm{Al}$ system at $1873 \mathrm{~K}$.

the higher Al range. Figure 6 shows the excess Gibbs free energy of the Ni-Al binary system $\left(\Delta G^{e x}\right)$ calculated from the $\mathrm{Ni}-\mathrm{Al}$ interaction parameters. Using our previously parameters, $\Delta G^{e x}$ changes from a negative value to a positive value in the higher Al range. It also deviated greatly from Ansara et al. $^{28)}$ which was well used in the phase diagram. This is because, in the previous study, the Ni-Al interaction was determined by fitting the large composition dependence of $\log K^{\prime}$ of $\mathrm{Fe}-\mathrm{Ni}$ alloy without ternary interaction terms. Although it will not be a problem for the Al deoxidation of the Fe-Ni system, it can cause serious errors in other systems. Therefore, we reassessed the Al deoxidation of $\mathrm{Fe}-\mathrm{Ni}$ alloy.

In the previous study, ${ }^{12)}$ the interaction between solvent elements $\left(\mathrm{Fe}-\mathrm{Ni}^{29)}\right)$ were taken from the values that are commonly used in the field of phase diagrams. On the other hand, the interactions between solvents and solutes (Ni$\left.\mathrm{Al},{ }^{12)} \mathrm{Fe}-\mathrm{Al},{ }^{12)} \mathrm{Fe}-\mathrm{O},{ }^{16)} \mathrm{Ni}-\mathrm{O}^{16)}\right)$ was determined from the deoxidation equilibrium, the Gibbs free energy change of the dissolution reaction and/or Wagner's interaction parameters. This means that the later value was obtained only from the dilute compositions. Therefore, as shown in Fig. 7, $\Delta G^{e x}$ of the $\mathrm{Fe}-\mathrm{Al}$ system calculated from the $\mathrm{Fe}-\mathrm{Al}$ interaction determined in our previous study ${ }^{12)}$ deviated from that of the Saunders's interaction ${ }^{30)}$ which was determined from a wide composition rage of the $\mathrm{Fe}-\mathrm{Al}$ system and is commonly used in the phase diagram. So, the $\mathrm{Fe}-\mathrm{Al}$ interaction parameter (Eqs. (13)-(17)) in this study was newly determined by 
fitting the dilute $\mathrm{Al}$ area with the value of Fukaya ${ }^{12)}$ and the higher $\mathrm{Al}$ area with the value of Saunders. ${ }^{30}$

$$
\begin{gathered}
\Omega_{\mathrm{Fe}-\mathrm{Al}}^{0}=-60072+10.43 T[\mathrm{~J} / \mathrm{mol}] \ldots \\
\Omega_{\mathrm{Fe}-\mathrm{Al}}^{1}=-42886-23.03 T[\mathrm{~J} / \mathrm{mol}] \ldots \\
\Omega_{\mathrm{Fe}-\mathrm{Al}}^{2}=-336944+172.0 T[\mathrm{~J} / \mathrm{mol}] \\
\Omega_{\mathrm{Fe}-\mathrm{Al}}^{3}=-246795+126.8 T[\mathrm{~J} / \mathrm{mol}] \\
\Omega_{\mathrm{Fe}-\mathrm{Al}}^{4}=368534-187.4 T[\mathrm{~J} / \mathrm{mol}] . .
\end{gathered}
$$

By introducing higher order $\mathrm{Al}-\mathrm{O}$ interaction parameters, the thermodynamic model of this study can also be used to calculate the deoxidation equilibrium over the complete composition range of the $\mathrm{Fe}-\mathrm{Al}$ system. However, except for the $\mathrm{Fe}-\mathrm{Al}-\mathrm{O}$ system, the $\mathrm{Al}$ deoxidation equilibrium with such higher $\mathrm{Al}$ content was not reported. Even though it can be used to calculate the higher $\mathrm{Al}$ range in the $\mathrm{Fe}-\mathrm{Cr}-\mathrm{Ni}$ alloy, the reliability of the calculation cannot be evaluated. Therefore, in this study, the previous Al-O interaction $^{12)}$ consisting of only the 1 st order parameter was used although the calculation validity of this parameter was limited to less than 0.5 mass\% $\%$ Al. Considering practical $\mathrm{Fe}-$ $\mathrm{Cr}-\mathrm{Ni}$ alloy compositions, excepting high Al special steels, this composition range is enough to apply in the actual engineering situations.

Re-assessment of the $\mathrm{Al}$ deoxidation in molten $\mathrm{Fe}-\mathrm{Ni}$ alloy was carried out with the $\mathrm{Fe}-\mathrm{Ni}-\mathrm{Al}$ ternary interaction parameters of Zhang ${ }^{31)}$ and the newly determined $\mathrm{Fe}-\mathrm{Al}$ interaction parameters. The $\mathrm{Ni}-\mathrm{Al}$ interaction parameter (Eqs. (18)-(20)) was determined from the composition dependence of $\log K^{\prime}$ for the $\mathrm{Al}$ deoxidation equilibrium in $\mathrm{Fe}-\mathrm{Ni}$ alloys. The details of how that was determined are described in a previous paper. ${ }^{12)}$ The calculated $\log K^{\prime}$ and experimental data of the $\mathrm{Al}$ deoxidation equilibrium in $\mathrm{Fe}-\mathrm{Ni}$ alloys ${ }^{2,5-12)}$ are shown in Fig. 8. Both calculated lines agree well with the reported values. The excess Gibbs free energy of Ni-Al system calculated using the newly determined $\mathrm{Ni}-\mathrm{Al}$ interaction parameters are also shown in Fig.

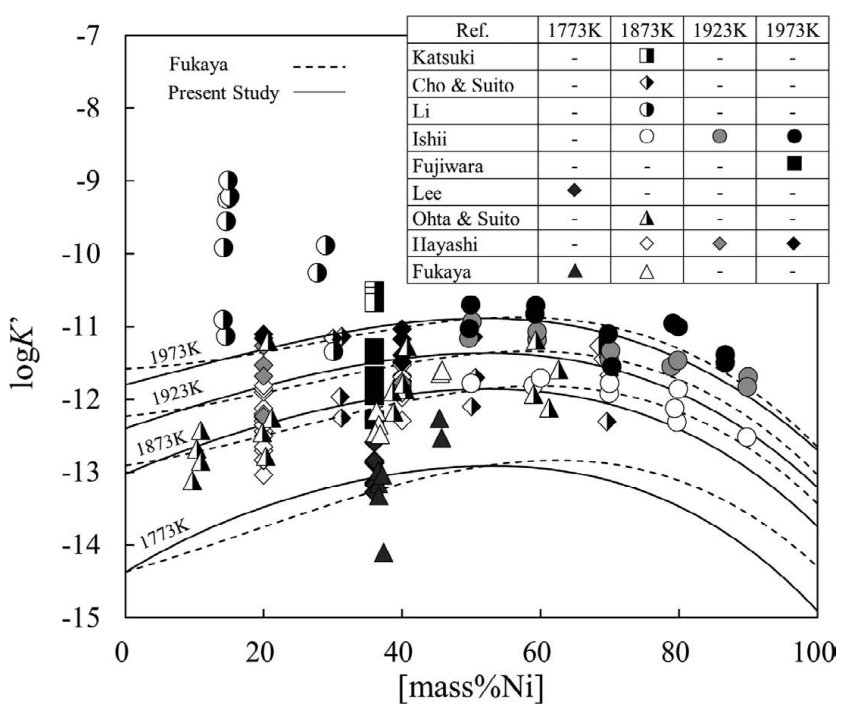

Fig. 8. Calculated and reported $\log K$, of the $\mathrm{Al}$ deoxidation equilibrium of the Fe-Ni system.
6. Using the new $\mathrm{Ni}-\mathrm{Al}$ interaction values, excess Gibbs free energy values similar to those of Ansara et al. ${ }^{28)}$ were obtained. This indicates that the re-assessed parameters are much more reliable than the previous value.

$$
\begin{aligned}
& \Omega_{\mathrm{Ni}-\mathrm{Al}}^{0}=-364875+117.7 T[\mathrm{~J} / \mathrm{mol}] \\
& \Omega_{\mathrm{Ni}-\mathrm{Al}}^{1}=-90760+39.16 T[\mathrm{~J} / \mathrm{mol}] \\
& \Omega_{\mathrm{Ni}-\mathrm{Al}}^{2}=87230-28.91 T[\mathrm{~J} / \mathrm{mol}] \ldots
\end{aligned}
$$

\subsection{Assessment in the $\mathrm{Fe}-\mathrm{Cr}-\mathrm{Al}-\mathrm{O}$ System}

Thermodynamic analysis in the $\mathrm{Fe}-\mathrm{Cr}$ system was carried out from the reported $\mathrm{Al}$ deoxidation equilibrium of the $\mathrm{Fe}-$ $\mathrm{Cr}$ alloys. ${ }^{1-4)}$ When the $\mathrm{Al}$ and $\mathrm{O}$ contents are small enough and the activity of $\mathrm{Al}_{2} \mathrm{O}_{3}$ is unity, the $\mathrm{Al}$ deoxidation equilibrium of $\mathrm{Fe}-\mathrm{Cr}$ alloys is simply expressed as in Eq. (21).

$$
\begin{aligned}
& \Delta G_{\mathrm{Al}_{2} \mathrm{O}_{3}}^{\circ}=R T \ln X_{\mathrm{Al}}{ }^{2} X_{\mathrm{O}}{ }^{3}+2 R T \ln \gamma_{\mathrm{Al}}+3 R T \ln \gamma_{\mathrm{O}} \\
& =R T \ln X_{\mathrm{Al}}^{2} X_{\mathrm{O}}{ }^{3}-5 \sum(n+1) X_{\mathrm{Fe}} X_{\mathrm{Cr}}\left(X_{\mathrm{Fe}}-X_{\mathrm{Cr}}\right)^{n} \Omega_{\mathrm{Fe}-\mathrm{Cr}}^{n} \\
& +2 \sum X_{\mathrm{Fe}}{ }^{n+1} \Omega_{\mathrm{Fe}-\mathrm{Al}}^{n}+2 \sum X_{\mathrm{Cr}}^{n+1} \Omega_{\mathrm{Cr}-\mathrm{Al}}^{n} \\
& +3 \sum X_{\mathrm{Fe}}{ }^{n+1} \Omega_{\mathrm{Fe}-\mathrm{O}}^{n}+3 \sum X_{\mathrm{Cr}}{ }^{n+1} \Omega_{\mathrm{Cr}-\mathrm{O}}^{n}
\end{aligned}
$$

Here, as the $\mathrm{Fe}-\mathrm{Al}$ and $\mathrm{Fe}-\mathrm{O}$ interactions used the same parameters as the previous $\mathrm{Fe}-\mathrm{Ni}$ re-assessment and reported values for $\mathrm{Fe}-\mathrm{Cr}^{29)}$ and $\mathrm{Cr}-\mathrm{O}^{24)}$ were used, all interaction terms except $\mathrm{Cr}-\mathrm{Al}$ were obtained. By transferring all terms of Eq. (21) except the $\mathrm{Cr}-\mathrm{Al}$ interaction, and defining $F_{\mathrm{Cr}-\mathrm{Al}}$, Eq. (22) was obtained.

$$
\begin{aligned}
& F_{\mathrm{Cr}-\mathrm{Al}}=\Delta G_{\mathrm{Al} 2} \mathrm{O}_{3}-R T \ln X_{\mathrm{Al}}{ }^{2} X_{\mathrm{O}}{ }^{3} \\
& +5 \sum(n+1) X_{\mathrm{Fe}} X_{\mathrm{Cr}}\left(X_{\mathrm{Fe}}-X_{\mathrm{Cr}}\right)^{n} \Omega_{\mathrm{Fe}-\mathrm{Cr}}^{n} \\
& -2 \sum X_{\mathrm{Fe}}{ }^{n+1} \Omega_{\mathrm{Fe}-\mathrm{Al}}^{n}-3 \sum X_{\mathrm{Fe}}{ }^{n+1} \Omega_{\mathrm{Fe}-\mathrm{O}}^{n}-3 \sum X_{\mathrm{Cr}}{ }^{n+1} \Omega_{\mathrm{Cr}-\mathrm{O}}^{n} \\
& =2 \sum X_{\mathrm{Cr}}{ }^{n+1} \Omega_{\mathrm{Cr}-\mathrm{Al}}^{n}
\end{aligned}
$$

Here $F_{\mathrm{Cr}-\mathrm{Al}}$ is simply expressed as an $n$ order function of $X_{\mathrm{Cr}} . F_{\mathrm{Cr}-\mathrm{Al}}$ calculated from the reported Al deoxidation equilibrium is shown in Fig. 9. In this figure, the solid lines are the fitting curves with the second order $\mathrm{Cr}-\mathrm{Al}$ interaction (Eqs. (23) and (24)).

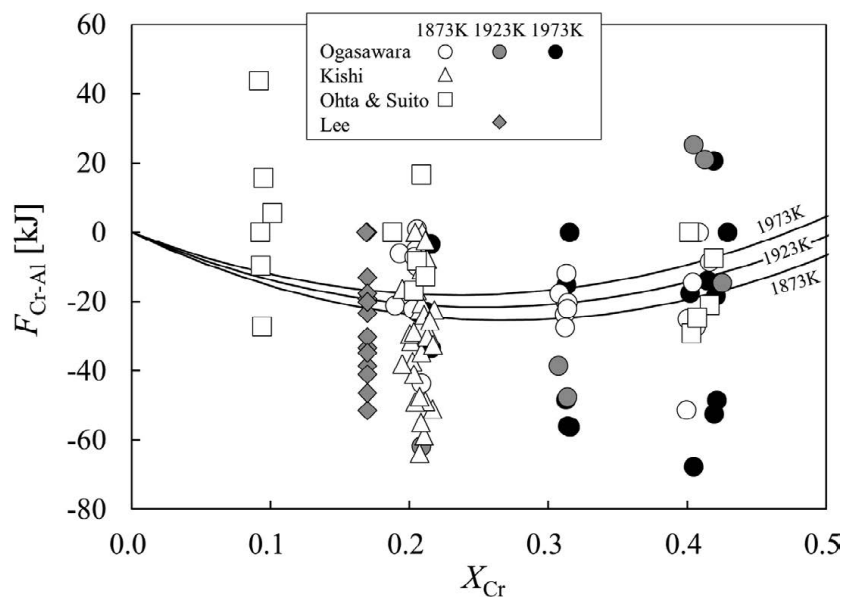

Fig. 9. Relation between $F_{\mathrm{Cr}-\mathrm{Al}}$ and $X_{\mathrm{Cr}}$. 


$$
\begin{gathered}
\Omega_{\mathrm{Cr}-\mathrm{Al}}^{0}=2548740-179.0 T[\mathrm{~J} / \mathrm{mol}] \\
\Omega_{\mathrm{Cr}-\mathrm{Al}}^{1}=-87250+133.2 T[\mathrm{~J} / \mathrm{mol}] \ldots
\end{gathered}
$$

Since the reported $\mathrm{Al}$ deoxidation equilibrium of $\mathrm{Fe}-\mathrm{Cr}$ alloys is limited with less than $40 \mathrm{mass} \% \mathrm{Cr}$, the tendency of the $F_{\mathrm{Cr}-\mathrm{A}}$ for the whole $\mathrm{Fe}-\mathrm{Cr}$ system is not clear. If $F_{\mathrm{Cr}-\mathrm{Al}}$ is drastically changed to the higher $\mathrm{Cr}$ range, higher order interaction will be required. The calculated and reported $\log K^{\prime}$ of the $\mathrm{Al}$ deoxidation equilibrium in $\mathrm{Fe}-\mathrm{Cr}$ alloys are shown in Fig. 10. The calculated lines with the newly obtained $\mathrm{Cr}-\mathrm{Al}$ interaction were found to be in good agreement with the reported values. This indicates that the second order interaction is enough for the compositions with less than $40 \mathrm{mass} \% \mathrm{Cr}$.

\subsection{Assessment in the $\mathrm{Fe}-\mathrm{Ni}-\mathrm{Cr}-\mathrm{Al}-\mathrm{O}$ System}

Since the $\mathrm{Al}$ deoxidation equilibriums in the $\mathrm{Fe}-\mathrm{Ni}$ and $\mathrm{Fe}-\mathrm{Cr}$ binary systems were determined, that of the $\mathrm{Fe}-\mathrm{Cr}-$ $\mathrm{Ni}$ system can also be calculated using the $\mathrm{Cr}-\mathrm{Ni}^{29)}$ and $\mathrm{Fe}-\mathrm{Cr}-\mathrm{Ni}^{32)}$ ternary interaction parameters.

The relationship between the calculated and experimental $\log K^{\prime}$ of the $\mathrm{Al}$ deoxidation equilibrium in $\mathrm{Fe}-\mathrm{Cr}-\mathrm{Ni}$ alloys at $1873 \mathrm{~K}$ for the same Fe molar fraction (about $X_{\mathrm{Fe}}=0.6$ ) and equivalent molar fraction of $\mathrm{Cr}\left(X_{\mathrm{Cr}} /\left(X_{\mathrm{Cr}}+X_{\mathrm{Ni}}\right)\right)$ is shown

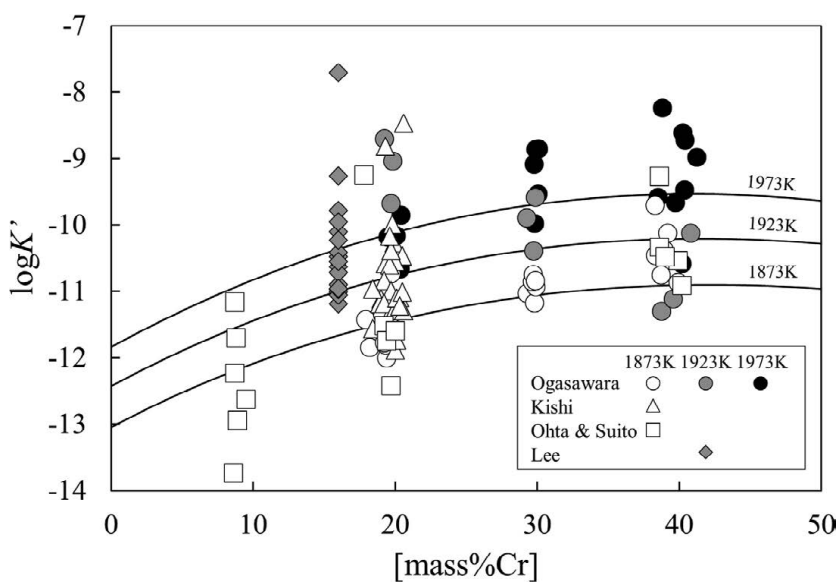

Fig. 10. Calculated and reported $\log K^{\prime}$ of the $\mathrm{Al}$ deoxidation equilibrium of the $\mathrm{Fe}-\mathrm{Cr}$ system.

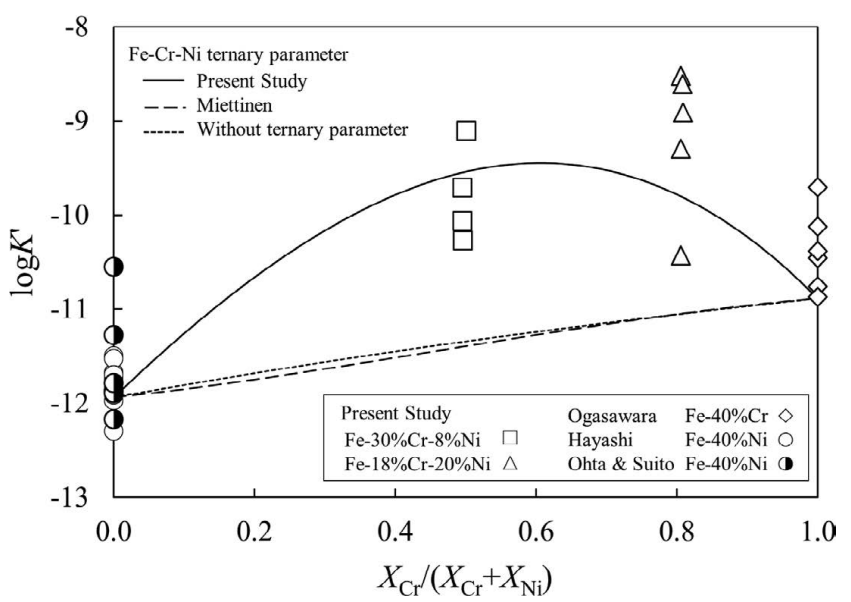

Fig. 11. Calculated and reported $\log K^{\prime}$ of the $\mathrm{Al}$ deoxidation equilibrium of the $\mathrm{Fe}-\mathrm{Ni}-\mathrm{Cr}$ system $\left(\mathrm{X}_{\mathrm{Fe}}=0.60\right)$ at 1873 $\mathrm{K}$. in Fig. 11. In this figure, both ends of the horizontal axis shows the values for the $\mathrm{Fe}-\mathrm{Cr}$ and $\mathrm{Fe}-\mathrm{Ni}$ binary systems which were already determined. The experimental values in

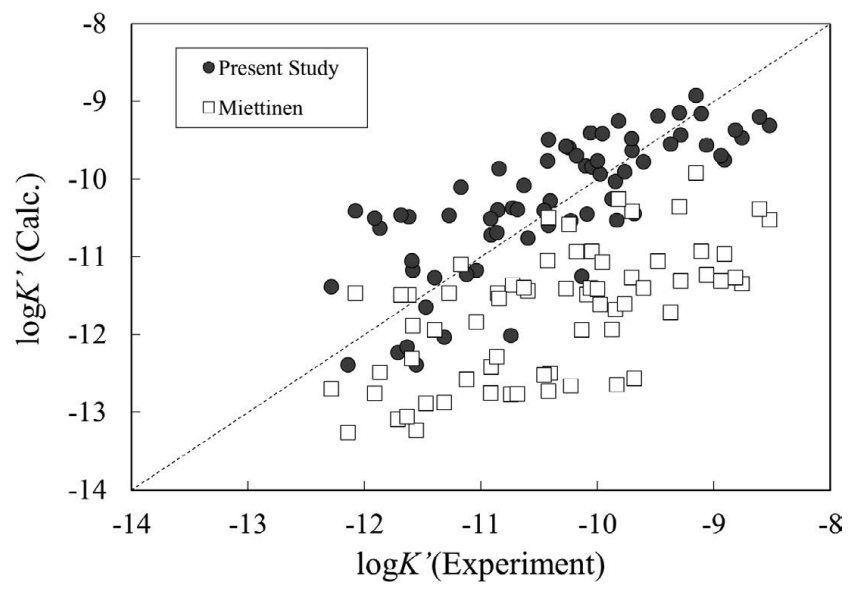

Fig. 12. Comparison between the calculated $\log K^{\prime}$ of the $\mathrm{Al}$ deoxidation equilibrium of the $\mathrm{Fe}-\mathrm{Ni}-\mathrm{Cr}$ system with different $\mathrm{Fe}-\mathrm{Cr}-\mathrm{Ni}$ ternary interaction parameter.

\begin{tabular}{|c|c|c|c|}
\hline & Value $[\mathrm{J} / \mathrm{mol}]$ & & Ref. \\
\hline$\Omega_{\mathrm{Fe}-\mathrm{Cr}}^{0}$ & -17737 & $+7.997 T$ & \multirow{2}{*}{ (29) } \\
\hline$\Omega_{\mathrm{Fe}-\mathrm{Cr}}^{1}$ & 1331 & & \\
\hline$\Omega_{\mathrm{Fe}-\mathrm{Ni}}^{0}$ & -16911 & $+5.162 T$ & \multirow{2}{*}{ (29) } \\
\hline$\Omega_{\mathrm{Fe}-\mathrm{Ni}}^{1}$ & 10180 & $-4.147 T$ & \\
\hline$\Omega_{\mathrm{Cr}-\mathrm{Ni}}^{0}$ & 318 & $-7.33 T$ & \multirow{2}{*}{ (29) } \\
\hline$\Omega_{\mathrm{Cr}-\mathrm{Ni}}^{1}$ & 16941 & $-6.37 T$ & \\
\hline$\Omega_{\mathrm{Fe}-\mathrm{Al}}^{0}$ & -69072 & $+10.43 T$ & \multirow{5}{*}{ Present Study } \\
\hline$\Omega_{\mathrm{Fe}-\mathrm{Al}}^{1}$ & 42886 & $-24.03 T$ & \\
\hline$\Omega_{\mathrm{Fe}-\mathrm{Al}}^{2}$ & -336944 & $+172.0 \mathrm{~T}$ & \\
\hline$\Omega_{\mathrm{Fe}-\mathrm{Al}}^{3}$ & -246795 & $+126.8 T$ & \\
\hline$\Omega_{\mathrm{Fe}-\mathrm{Al}}^{4}$ & 368534 & $-187.4 T$ & \\
\hline$\Omega_{\mathrm{Cr}-\mathrm{Al}}^{0}$ & 258740 & $-179.0 T$ & \multirow{2}{*}{ Present Study } \\
\hline$\Omega_{\mathrm{Cr}-\mathrm{Al}}^{1}$ & -87250 & $+133.2 T$ & \\
\hline$\Omega_{\mathrm{Ni}-\mathrm{Al}}^{0}$ & -364875 & $+117.7 T$ & \multirow{3}{*}{ Present Study } \\
\hline$\Omega_{\mathrm{Ni}-\mathrm{Al}}^{1}$ & -90760 & $+39.16 T$ & \\
\hline$\Omega_{\mathrm{Ni}-\mathrm{Al}}^{2}$ & 87230 & $-28.91 T$ & \\
\hline$\Omega_{\mathrm{Fe}-\mathrm{O}}^{0}$ & -415400 & $+142.4 T$ & \multirow{2}{*}{ (16) } \\
\hline$\Omega_{\mathrm{Fe}-\mathrm{O}}^{1}$ & 298300 & $-117.8 T$ & \\
\hline$\Omega_{\mathrm{Cr}-\mathrm{O}}^{0}$ & -52870 & $-24 T$ & \multirow{2}{*}{$(24)$} \\
\hline$\Omega_{\mathrm{Cr}-\mathrm{O}}^{1}$ & -498200 & $+235 T$ & \\
\hline$\Omega_{\mathrm{Ni}-\mathrm{O}}^{0}$ & -106500 & $+44.80 T$ & \multirow{2}{*}{ (16) } \\
\hline$\Omega_{\mathrm{Ni}-\mathrm{O}}^{1}$ & 35500 & $-15.920 T$ & \\
\hline$\Omega_{\mathrm{Al}-\mathrm{O}}^{0}$ & -5626500 & $+1635 T$ & (12) \\
\hline$\Omega_{\mathrm{FeCrNi}}^{\mathrm{Fe}}$ & 2623669 & $-1171 T$ & \multirow{3}{*}{ Present Study } \\
\hline$\Omega_{\mathrm{FeCrNi}}^{\mathrm{Cr}}$ & 2748122 & $-1391 T$ & \\
\hline$\Omega_{\mathrm{FeCrNi}}^{\mathrm{Ni}}$ & -4365536 & $+2277 \mathrm{~T}$ & \\
\hline$\Omega_{\mathrm{FeNiAl}}^{\mathrm{Fe}}$ & 57195 & & \multirow{3}{*}{ (31) } \\
\hline$\Omega_{\mathrm{FeNiAl}}^{\mathrm{Ni}}$ & -8441 & & \\
\hline$\Omega_{\mathrm{FeNiAl}}^{\mathrm{Al}}$ & -62066 & $+11.763 T$ & \\
\hline$\Delta G_{A l 2 O 3}^{\circ}$ & -1682300 & $+324.15 T$ & (27) \\
\hline
\end{tabular}

Table 3. List of interaction parameters used in this study. 
$\mathrm{Fe}-30 \%$ mass $\mathrm{Cr}-8 \mathrm{mass} \% \mathrm{Ni}$ and $\mathrm{Fe}-18$ mass $\% \mathrm{Cr}-20 \mathrm{mass} \% \mathrm{Ni}$ from the present study, $\mathrm{Fe}-40$ mass $\% \mathrm{Cr}$ from Ogasawara, $\mathrm{Fe}-40 \%$ mass $\%$ Ni from Ohta \& Suito ${ }^{2)}$ and Hayashi ${ }^{11)}$ were also plotted. As shown in Fig. $11, \log K^{\prime}$ of the $\mathrm{Fe}-\mathrm{Cr}-\mathrm{Ni}$ alloy was an upward convex curve and the value is larger than that of the $\mathrm{Fe}-\mathrm{Ni}$ and $\mathrm{Fe}-\mathrm{Cr}$ systems. It cannot be expressed by the calculation without the $\mathrm{Fe}-\mathrm{Cr}-\mathrm{Ni}$ ternary parameter nor with the reported ternary parameter. ${ }^{32)}$ Although it can be modified by introducing the $\mathrm{Cr}-\mathrm{Ni}-\mathrm{Al}$ and/or $\mathrm{Cr}-\mathrm{Ni}-\mathrm{O}$ ternary interaction terms as a fitting parameter, the interaction becomes too big at the higher $\mathrm{Ni}$ and $\mathrm{Cr}$ contents. It might be unrealistic. Therefore, in this study, the $\mathrm{Fe}-\mathrm{Cr}-\mathrm{Ni}$ interaction parameter was modified. To fit the experimental data for the $\mathrm{Fe}-\mathrm{Cr}-\mathrm{Ni}$ alloy of the present study as well as that of Ohta \& Suito, ${ }^{2)}$ a $\mathrm{Fe}-\mathrm{Cr}-\mathrm{Ni}$ ternary interaction parameter was determined as in Eqs. (25)-(27). In Fig. 12, the calculated $\log K^{\prime}$ was compared with the experimental values. It is clear that calculation was improved by using the optimized parameter in this study.

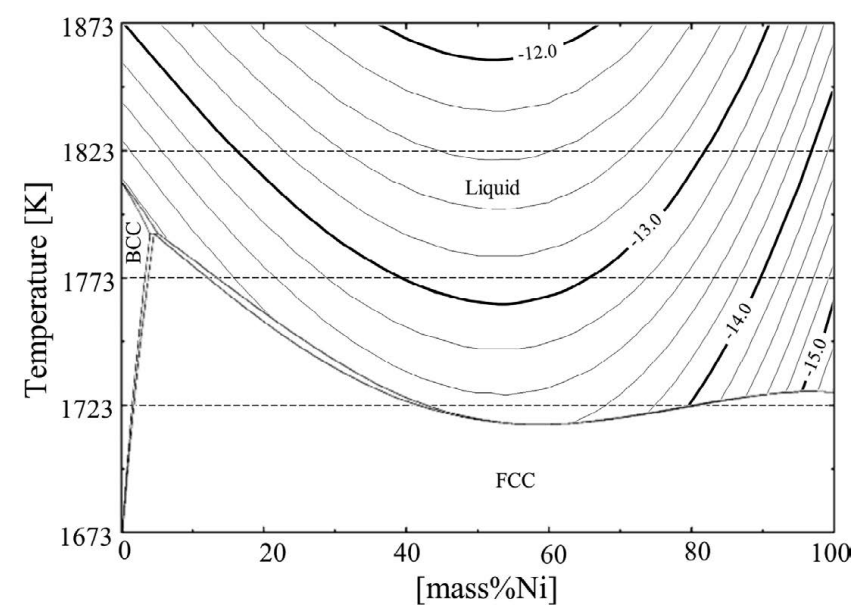

Fig. 13. Calculated $\log K^{\prime}$ of the $\mathrm{Al}$ deoxidation equilibrium of the $\mathrm{Fe}-\mathrm{Ni}$ system on the phase diagram.

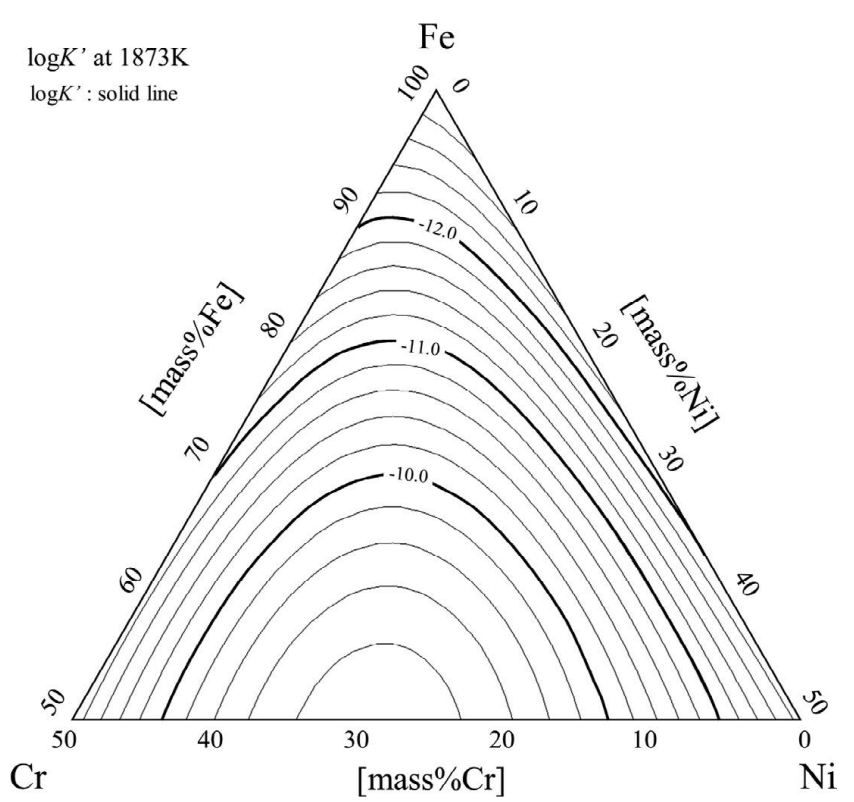

Fig. 14. Calculated $\log K^{\prime}$ of the $\mathrm{Al}$ deoxidation equilibrium of the $\mathrm{Fe}-\mathrm{Cr}-\mathrm{Ni}$ system at $1873 \mathrm{~K}$.

$$
\begin{gathered}
\Omega_{\mathrm{FeCrNi}}^{\mathrm{Fe}}=2623669-1171 T[\mathrm{~J} / \mathrm{mol}] \ldots \\
\Omega_{\mathrm{FeCrNi}}^{\mathrm{Cr}}=2748122-1391 T[\mathrm{~J} / \mathrm{mol}] \ldots \\
\Omega_{\mathrm{FeCrNi}}^{\mathrm{Ni}}=-4365536+2277 T[\mathrm{~J} / \mathrm{mol}] .
\end{gathered}
$$

However, it cannot evaluate the reliability of the $\mathrm{Fe}-$ $\mathrm{Cr}-\mathrm{Ni}$ parameter reported by Miettinen. ${ }^{32)}$ The values and temperature dependence of the newly determined $\mathrm{Fe}-\mathrm{Cr}-$ $\mathrm{Ni}$ parameter were too big. It might involve other ternary parameters and/or higher order interactions which were not considered in this study. Therefore, this parameter can be used only for the $\mathrm{Al}$ deoxidation equilibrium in $\mathrm{Fe}-\mathrm{Cr}-\mathrm{Ni}$ alloys and can cause errors when used for other purposes or in other alloy systems.

Although the parameter usage is limited, the Al deoxidation equilibrium of iron rich $\mathrm{Fe}-\mathrm{Cr}-\mathrm{Ni}$ alloys can be calculated precisely. The deoxidation equation is expressed in Eq. (28) with the interaction parameters used in this study. All parameters are shown in Table 3.

$$
\begin{aligned}
& \Delta G_{f, \mathrm{Al}_{2} \mathrm{O}_{3}}^{\circ}=R T \ln X_{\mathrm{Al}}^{2} X_{\mathrm{O}^{3}}^{3}-R T \ln a_{\mathrm{Al}_{2} \mathrm{O}_{3}} \\
& -5 X_{\mathrm{Fe}} X_{\mathrm{Fe}} \Omega_{\mathrm{Fe}-\mathrm{Cr}}^{0}-10 X_{\mathrm{Fe}} X_{\mathrm{Cr}}\left(X_{\mathrm{Fe}}-X_{\mathrm{Cr}}\right) \Omega_{\mathrm{Fe}-\mathrm{Cr}}^{1} \\
& -5 X_{\mathrm{Fe}} X_{\mathrm{Fe}} \Omega_{\mathrm{Fe}-\mathrm{Ni}}^{0}-10 X_{\mathrm{Fe}} X_{\mathrm{Ni}}\left(X_{\mathrm{Fe}}-X_{\mathrm{Ni}}\right) \Omega_{\mathrm{Fe}-\mathrm{Ni}}^{1} \\
& -5 X_{\mathrm{Cr}} X_{\mathrm{Cr}} \Omega_{\mathrm{Cr}-\mathrm{Ni}}^{0}-10 X_{\mathrm{Cr}} X_{\mathrm{Ni}}\left(X_{\mathrm{Cr}}-X_{\mathrm{Ni}}\right) \Omega_{\mathrm{Cr}-\mathrm{Ni}}^{1} \\
& +X_{\mathrm{Fe}}\left(3-5 X_{\mathrm{O}}\right) \Omega_{\mathrm{Fe}-\mathrm{O}}^{0} \\
& +X_{\mathrm{Fe}}\left(3 X_{\mathrm{Fe}}-6 X_{\mathrm{O}}-10 X_{\mathrm{Fe}} X_{\mathrm{O}}+10 X_{\mathrm{O}}^{2}\right) \Omega_{\mathrm{Fe}-\mathrm{O}}^{1} \\
& +X_{\mathrm{Cr}}\left(3-5 X_{\mathrm{O}}\right) \Omega_{\mathrm{Cr}-\mathrm{O}}^{0} \\
& +X_{\mathrm{Cr}}\left(3 X_{\mathrm{Cr}}-6 X_{\mathrm{O}}-10 X_{\mathrm{Cr}} X_{\mathrm{O}}+10 X_{\mathrm{O}}^{2}\right) \Omega_{\mathrm{Cr}-\mathrm{O}}^{1} \\
& +X_{\mathrm{Ni}}\left(3-5 X_{\mathrm{O}}\right) \Omega_{\mathrm{Ni}-\mathrm{O}}^{0} \\
& +X_{\mathrm{Ni}}\left(3 X_{\mathrm{Ni}}-6 X_{\mathrm{O}}-10 X_{\mathrm{Ni}} X_{\mathrm{O}}+10 X_{\mathrm{O}}^{2}\right) \Omega_{\mathrm{Ni}-\mathrm{O}}^{1} \\
& +X_{\mathrm{Fe}}\left(2-5 X_{\mathrm{Al}}\right) \Omega_{\mathrm{Fe}-\mathrm{Al}}^{0} \\
& +X_{\mathrm{Fe}}\left(2 X_{\mathrm{Fe}}-4 X_{\mathrm{Al}}-10 X_{\mathrm{Fe}} X_{\mathrm{Al}}+10 X_{\mathrm{Al}}^{2}\right) \Omega_{\mathrm{Fe}-\mathrm{Al}}^{1} \\
& +X_{\mathrm{Fe}}\left(X_{\mathrm{Fe}}-X_{\mathrm{Al}}\right)\left(2 X_{\mathrm{Fe}}-6 X_{\mathrm{Al}}-15 X_{\mathrm{Fe}} X_{\mathrm{Al}}+15 X_{\mathrm{Al}}^{2}\right) \Omega_{\mathrm{Fe}-\mathrm{Al}}^{2} \\
& +X_{\mathrm{Fe}}\left(X_{\mathrm{Fe}}-X_{\mathrm{Al}}\right)^{2}\left(2 X_{\mathrm{Fe}}-8 X_{\mathrm{Al}}-20 X_{\mathrm{Fe}} X_{\mathrm{Al}}+20 X_{\mathrm{Al}}^{2}\right) \Omega_{\mathrm{Fe}-\mathrm{Al}}^{3} \\
& +X_{\mathrm{Fe}}\left(X_{\mathrm{Fe}}-X_{\mathrm{Al}}\right)^{3}\left(2 X_{\mathrm{Fe}}-10 X_{\mathrm{Al}}-25 X_{\mathrm{Fe}} X_{\mathrm{Al}}+25 X_{\mathrm{Al}}^{2}\right) \Omega_{\mathrm{Fe}-\mathrm{Al}}^{4} \\
& +X_{\mathrm{Cr}}\left(2-5 X_{\mathrm{Al}}\right) \Omega_{\mathrm{Cr}-\mathrm{Al}}^{0} \\
& +X_{\mathrm{Cr}}\left(2 X_{\mathrm{Cr}}-4 X_{\mathrm{Al}}-10 X_{\mathrm{Cr}} X_{\mathrm{Al}}+10 X_{\mathrm{Al}}^{2}\right) \Omega_{\mathrm{Cr}-\mathrm{Al}}^{1} \\
& +X_{\mathrm{Ni}}\left(2-5 X_{\mathrm{Al}}\right) \Omega_{\mathrm{Ni}-\mathrm{Al}}^{0} \\
& +X_{\mathrm{Ni}}\left(2 X_{\mathrm{Ni}}-4 X_{\mathrm{Al}}-10 X_{\mathrm{Ni}} X_{\mathrm{Al}}+10 X_{\mathrm{Al}}^{2}\right) \Omega_{\mathrm{Ni}-\mathrm{Al}}^{1} \\
& +X_{\mathrm{Ni}}\left(X_{\mathrm{Ni}}-X_{\mathrm{Al}}\right)\left(2 X_{\mathrm{Ni}}-6 X_{\mathrm{Al}}-15 X_{\mathrm{Ni}} X_{\mathrm{Al}}+15 X_{\mathrm{Al}}^{2}\right) \Omega_{\mathrm{Ni}-\mathrm{Al}}^{2} \\
& +\left(3 X_{\mathrm{Al}}+2 X_{\mathrm{O}}-5 X_{\mathrm{Al}} X_{\mathrm{O}}\right) \Omega_{\mathrm{Al}-\mathrm{O}}^{1} \\
& +X_{\mathrm{Fe}} X_{\mathrm{Ni}}\left(2-2 Y_{\mathrm{Al}}-10 X_{\mathrm{Al}}\right)\left(Y_{\mathrm{Al}} \Omega_{\mathrm{AlFeNi}}^{\mathrm{Al}}+Y_{\mathrm{Fe}} \Omega_{\mathrm{AlFeNi}}^{\mathrm{Fe}}+Y_{\mathrm{Ni}} \Omega_{\mathrm{AlFeNi}}^{\mathrm{Ni}}\right) \\
& +2 Y_{\mathrm{Al}} X_{\mathrm{Fe}} X_{\mathrm{Ni}} \Omega_{\mathrm{AlFeNi}}^{\mathrm{Al}} \\
& -10 X_{\mathrm{Fe}} X_{\mathrm{Cr}} X_{\mathrm{Ni}}\left(Y_{\mathrm{Fe}} \Omega_{\mathrm{FeCrNi}}^{\mathrm{Fe}}+Y_{\mathrm{Cr}} \Omega_{\mathrm{FeCrNi}}^{\mathrm{Cr}}++Y_{\mathrm{Ni}} \Omega_{\mathrm{FeCrNi}}^{\mathrm{Ni}}\right)
\end{aligned}
$$

Since these parameters were optimized from the deoxidation equilibrium between 1773 and $1973 \mathrm{~K}$, it might also be available at the liquidus temperature. Using this 


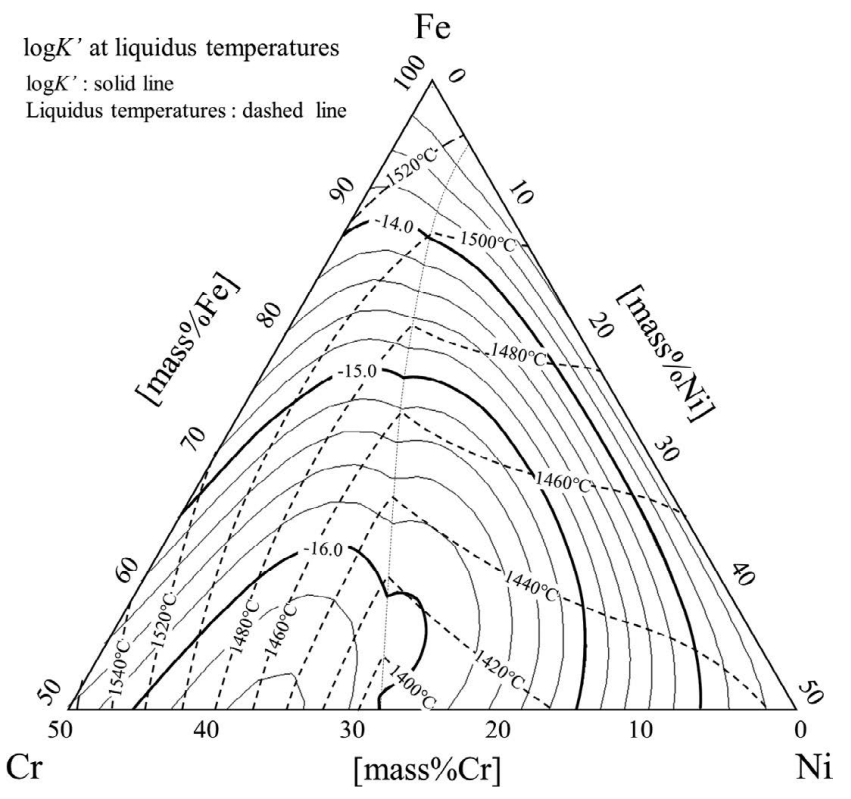

Fig. 15. Calculated $\log K^{\prime}$ of the Al deoxidation equilibrium of the $\mathrm{Fe}-\mathrm{Cr}-\mathrm{Ni}$ system at liquidus temperatures.

equation and the determined parameters, the Al deoxidation equilibrium was calculated for the complete composition range of $\mathrm{Fe}-\mathrm{Ni}$ alloys and $\mathrm{Fe}-\mathrm{Cr}-\mathrm{Ni}$ alloy with more than $50 \mathrm{mass} \% \mathrm{Fe}$ at the steel refining and casting temperatures. For example, the calculated $\log K^{\prime}(\mathrm{Al}=0.01$ mass $\%)$ described on the $\mathrm{Fe}-\mathrm{Ni}$ phase diagram is shown in Fig. 13. Also, the $\log K^{\prime}$ in $\mathrm{Fe}-\mathrm{Cr}-\mathrm{Ni}$ alloys at $1873 \mathrm{~K}$ and at the liquidus temperatures are shown in Figs. 14 and 15, respectively. In those figures, the phase diagrams and liquidus temperatures were calculated using FactSage. ${ }^{33)}$ This information is of significant help for the prediction and/or control of secondary inclusions in the practical steelmaking operations.

\section{Conclusion}

The Al deoxidation equilibrium in molten $\mathrm{Fe}-\mathrm{Cr}-\mathrm{Ni}$ alloy was experimentally determined at 1773 and 1873 $\mathrm{K}$. A thermodynamic assessment based on the sub-regular solution model using a Redlich-Kister type polynomial was carried out. In the $\mathrm{Fe}-\mathrm{Ni}-\mathrm{Al}-\mathrm{O}, \mathrm{Fe}-\mathrm{Cr}-\mathrm{Al}-\mathrm{O}$ and $\mathrm{Fe}-\mathrm{Cr}-$ $\mathrm{Ni}-\mathrm{Al}-\mathrm{O}$ systems, $\mathrm{Fe}-\mathrm{Al}, \mathrm{Ni}-\mathrm{Al}, \mathrm{Cr}-\mathrm{Al}$ and $\mathrm{Fe}-\mathrm{Cr}-\mathrm{Ni}$ interaction parameters were newly determined. Using these parameters, the $\mathrm{Al}$ deoxidation equilibrium in the complete composition range of $\mathrm{Fe}-\mathrm{Ni}$ alloys and the $\mathrm{Fe}$ rich $\mathrm{Fe}-\mathrm{Cr}-$ $\mathrm{Ni}$ alloys $(>50 \mathrm{mass} \% \mathrm{Fe})$ can be described at the liquidus temperature and to $1973 \mathrm{~K}$ with lower $\mathrm{Al}$ composition $(<0.5$ mass $\% \mathrm{Al})$.

\section{REFERENCES}

1) M. Kishi, R. Inoue and H. Suito: ISIJ Int., 34 (1994), 859

2) H. Ohta and H. Suito: ISIJ Int., 43 (2003), 1301.

3) S. B. Lee, J. H. Choi, H. G. Lee, P. C. H. Rhee and S. M. Jung: Metall. Mater. Trans. B, 36 (2005), 414.

4) Y. Ogasawara and T. Miki: CAMP-ISIJ, 23 (2010), 925 (in Japanese), CD-ROM.

5) J. Katsuki and T. Yamauchi: CAMP-ISIJ, 7 (1994), 1076 (in Japanese).

6) S. W. Cho and H. Suito: Steel Res., 66 (1995), 237.

7) G. Li, R. Inoue and H. Suito: Steel Res., 67 (1996), 528

8) F. Ishii, S. Ban-ya and M. Hino: ISIJ Int., 36 (1996), 25.

9) H. Fujiwara, A. Hattori and E. Ichise: Tetsu-to-Hagané, 85 (1999), 201 (in Japanese).

10) S. B. Lee, S. M. Jung, H. G. Lee and C. H. Rhee: ISIJ Int., 42 (2002), 679.

11) A. Hayashi, T. Uenishi, H. Kandori, T. Miki and M. Hino: ISIJ Int., 48 (2008), 1533.

12) H. Fukaya, K. Kajikawa, A. Malfliet, B. Blanpain and M. Guo: Metall. Mater. Trans. B, 49 (2018), 2389.

13) M. Hillert and L.-I. Staffansson: Acta Chem. Scand., 24 (1970), 3618.

14) N. Saunders and A. P. Miodownik: Calphad, Calculation of Phase Diagrams, A Comprehensive Guide, Pergamon, Oxford, UK, (1988), 91.

15) T. Miki and M. Hino: ISIJ Int., 44 (2004), 1800

16) T. Miki and M. Hino: ISIJ Int., 45 (2005), 1848.

17) C. Wagner: Thermodynamics of Alloys, Addison-Wesley Press, Cambridge, MA, (1952), 47.

18) Y. Kang, M. Thunman, D. Sichen, T. Morohoshi, K. Mizukami and K. Morita: ISIJ Int., 49 (2009), 1483.

19) M. K. Paek, J. M. Jang, Y. B. Kang and J. J. Pak: Metall. Mater. Trans. B, 46 (2015), 1826.

20) M. K. Paek, J. J. Pak and Y. B. Kang: Metall. Mater. Trans. B, 46 (2015), 2224.

21) W. Y. Cha, T. Nagasaka, T. Miki, Y. Sasaki and M. Hino: ISIJ Int., 46 (2006), 996.

22) W. Y. Cha, T. Miki, Y. Sasaki and M. Hino: ISIJ Int., 48 (2008), 729.

23) S. H. Seok, T. Miki and M. Hino: ISIJ Int., 49 (2009), 804.

24) S. H. Seok, T. Miki and M. Hino: ISIJ Int., 49 (2009), 1850.

25) M. Yonemoto, T. Miki and M. Hino: ISIJ Int., 48 (2008), 755.

26) R. Yamamoto, H. Fukaya, N. Satoh, T. Miki and M. Hino: ISIJ Int., 51 (2011), 895.

27) M. W. Chase, Jr. ed.: NIST-JANAF Thermochemical Tables, 4th ed., J. Phys. Chem. Ref. Data, American Institute of Physics, Melville, NY, (1998), 154.

28) I. Ansara, N. Dupin, H. L. Lukas and B. Sundman: J. Alloy. Compd., 247 (1997), 20.

29) B.-J. Lee: Calphad, 17 (1993), 251.

30) N. Saunders: COST 507, Thermochemical Database for Light Metal Alloys, ed. by I. Ansara et al., European Communities, Luxemburg, (1998), 34

31) L. Zhang, J. Wang, Y. Du, R. Hu, P. Nash, X. G. Lu and C. Jiang: Acta Mater., 57 (2009), 5324.

32) J. Miettinen: Calphad, 23 (1999), 249.

33) C. W. Bale, E. Bélisle, P. Chartrand, S. A. Decterov, G. Eriksson, K. Hack, I. H. Jung, Y. B. Kang, J. Melançon, A. D. Pelton, C. Robelin and S. Petersen: Calphad, 33 (2009), 295. 